\title{
Competition and coexistence of sulfate-reducing bacteria, acetogens and methanogens in a lab-scale anaerobic bioreactor as affected by changing substrate to sulfate ratio
}

\author{
Shabir A. Dar • Robbert Kleerebezem • \\ Alfons J. M. Stams • J. Gijs Kuenen • Gerard Muyzer
}

Received: 20 November 2007 / Revised: 29 January 2008 / Accepted: 29 January 2008 / Published online: 28 February 2008

(C) The Author(s) 2008

\begin{abstract}
The microbial population structure and function of natural anaerobic communities maintained in lab-scale continuously stirred tank reactors at different lactate to sulfate ratios and in the absence of sulfate were analyzed using an integrated approach of molecular techniques and chemical analysis. The population structure, determined by denaturing gradient gel electrophoresis and by the use of oligonucleotide probes, was linked to the functional changes in the reactors. At the influent lactate to sulfate molar ratio of $0.35 \mathrm{~mol} \mathrm{~mol}^{-1}$, i.e., electron donor limitation, lactate oxidation was mainly carried out by incompletely oxidizing sulfate-reducing bacteria, which formed $80-85 \%$ of the total bacterial population. Desulfomicrobium- and Desulfovibriolike species were the most abundant sulfate-reducing bacteria. Acetogens and methanogenic Archaea were mostly outcompeted, although less than $2 \%$ of an acetogenic population could still be observed at this limiting concentration of lactate. In the near absence of sulfate (i.e., at very high lactate/sulfate ratio), acetogens and methanogenic Archaea were the dominant microbial communities. Acetogenic bacteria represented by Dendrosporobacter quercicolus-like species formed more than $70 \%$ of the population, while methanogenic bacteria related to uncultured Archaea comprising about $10-15 \%$ of the microbial community. At an influent lactate to sulfate
\end{abstract}

S. A. Dar $\cdot$ R. Kleerebezem · J. G. Kuenen $\cdot$ G. Muyzer $(\bowtie)$ Department of Biotechnology, Delft University of Technology, NL-2628 BC Delft, The Netherlands

e-mail: g.muyzer@tudelft.nl

A. J. M. Stams

Laboratory of Microbiology, Wageningen University,

Wageningen, The Netherlands molar ratio of $2 \mathrm{~mol} \mathrm{~mol}^{-1}$, i.e., under sulfate-limiting conditions, a different metabolic route was followed by the mixed anaerobic community. Apparently, lactate was fermented to acetate and propionate, while the majority of sulfidogenesis and methanogenesis were dependent on these fermentation products. This was consistent with the presence of significant levels (40-45\% of total bacteria) of $D$. quercicolus-like heteroacetogens and a corresponding increase of propionate-oxidizing Desulfobulbus-like sulfate-reducing bacteria ( $20 \%$ of the total bacteria). Methanogenic Archaea accounted for $10 \%$ of the total microbial community.

Keywords Anaerobic consortia. DGGE - FISH .

Acetogens $\cdot$ Methanogens $\cdot$ Sulfate-reducing bacteria

\section{Introduction}

The anaerobic digestion of organic material is accomplished by the concerted action of various trophic groups of bacteria (Schink et al. 1992). The soluble organic compounds are degraded to $\mathrm{CH}_{4}, \mathrm{CO}_{2}$, and $\mathrm{H}_{2} \mathrm{~S}$ via a syntropic interaction of fermentative and acetogenic bacteria with methanogens or sulfate-reducing bacteria (SRB). The electrons for $\mathrm{CO}_{2}$ reduction to methane or acetate, or sulfate reduction to sulfide are derived from the fermentative metabolism. The fermentative metabolism may include homoacetogenic or heteroacetogenic microorganisms depending upon whether acetic acid is the only major metabolic product (Drake 1994; Thauer et al. 1977) or other organic acids, such as propionic acid, in addition to acetic acid are produced (Seeliger et al. 2002). The products of fermentative acetogenesis and $\mathrm{CO}_{2}$-dependent homoacetogenesis can serve as substrates for acetate- and propionate- 
oxidizing SRB or acetoclastic methanogens depending upon the presence or absence of sulfate as electron acceptor. SRB are believed to outcompete methanogens in the presence of nonlimiting sulfate concentrations because they compete better for common substrates. This is explained on the basis of their kinetic properties $\left(K_{\mathrm{s}}\right.$ and $\left.\mu_{\max }\right)$ and given the favourable thermodynamic conditions (Ward and Winfrey 1985; Widdel 1988). In contrast, methanogens tend to dominate in low-sulfate environments (Stams 1994).

In most anaerobic environments, hydrogen is present as an intermediate for which SRB, hydrogenotrophic methanogens and homoacetogens will compete. Under standard conditions, sulfate reduction and methanogenesis are thermodynamically more favourable than homoacetogenesis. However, due to the interspecies transfer of fermentation products, such as hydrogen, the real thermodynamic values may be far from standard conditions and even less to reverse reactions. Studies with the sludge from the bioreactors have indicated that hydrogen is mainly consumed by SRB when $\mathrm{H}_{2}$ is limiting and sufficient sulfate is present (Isa et al. 1986). However, when $\mathrm{H}_{2} / \mathrm{CO}_{2}$ was added as the sole substrate, a coexistence of heterotrophic SRB and homoacetogens was reported by Weijma et al. (2002), suggesting that when SRB are dependent for growth on homoacetogens, it is likely that the growth kinetics of homoacetogens determines the competition (Stams et al. 2005).

The composition of the influent chemical oxygen demand (COD; electron donor) to $\mathrm{SO}_{4}^{2-}$ ratio tends to have a significant effect on the competition for electron flow between different microbial communities (McCartney and Oleszkiewics 1993). The theoretical $\mathrm{COD} / \mathrm{SO}_{4}^{2-}$ mass ratio needed to achieve complete removal of organic matter is 0.67 , assuming that eight electrons are transferred per molecule of sulfate (Lens et al. 1998). In general, low and high $\mathrm{COD} / \mathrm{SO}_{4}^{2-}$ mass ratios should favor sulfidogenesis and methanogenesis, respectively. However, values reported in the literature vary considerably (Annachhatre and Suktrakoolvait 2001; Choi and Rim 1991; Mizuno et al. 1994). Although the effect on the major processes like sulfidogenesis and methanogenesis on the whole has been well studied (McCartney and Oleszkiewicz 1993), our understanding of its influence on the diversity and dynamics of the microbial communities is still limited. This is partially due to the limitations of the traditional microbiological techniques, including pure culture isolations, most probable number estimation, selective enrichments, etc. Fortunately, molecular techniques, like denaturing gradient gel electrophoresis (DGGE; Muyzer et al. 1993) and fluorescence in situ hybridization (FISH; Amann et al. 1995), have provided alternative approaches to overcome the limitations associated with culture-based analyses.
DGGE profiling of 16S rRNA gene fragments amplified from both genomic DNA and reverse-transcribed RNA, i.e., cDNA not only determines the presence and distribution but also the actively growing members in the mixed microbial communities (Dar et al. 2007a). FISH, on the other hand, allows for the identification and quantification at the level of populations and even single cells (Amann et al. 1995).

In the present study, the structure and function of anaerobic communities maintained in lab-scale continuously stirred tank reactors (CSTR) under sulfidogenic and nonsulfidogenic conditions was investigated. An integrated approach of molecular techniques including DGGE and FISH together with chemical analysis was used to link the microbial population dynamics with changes in the lactate (electron donor) concentration and sulfate availability. The focus of our study was the competition and interaction between the dominant microbial communities of SRB, acetogens and methane-producing Archaea.

\section{Materials and methods}

\section{Reactor operation}

The schematic representation of the experimental design is given in Fig. 1. The start-up reactor (R-0) was inoculated with sludge from a methanogenic wastewater treatment plant treating lactate-containing wastewater. The reactor was operated in a continuous mode for about five to six volume changes at a dilution rate of $0.02 \mathrm{~h}^{-1}$ with lactate as the only electron donor and maintained under excess of sulfate. The lactate (12 electron) to sulfate ( 8 electron) molar ratio $(r)$ was $0.65 \mathrm{~mol} \mathrm{~mol}^{-1}$. The culture in the reactor R-0 was used as an inoculum for the reactors, R1 and $\mathrm{R} 2$. The reactors $\mathrm{R} 1$ and $\mathrm{R} 2$ were operated at $30^{\circ} \mathrm{C}$ with a working volume of 21 and at two different concentrations of lactate, 3.5 and $20 \mathrm{mM}$, respectively. Sulfate was fed to the reactors at a concentration of $10.32 \mathrm{mM}$, i.e., at ratios far below and far above the theoretical ratio of 0.67 . Nonsulfidogenic conditions were applied to reactor R2 by further reducing influent sulfate feed and reducing the lactate concentration to $6.7 \mathrm{mM}$ $(r=20.9)$. The composition of influent mineral medium was as follows (concentration in $\mathrm{mM}$ ): $\mathrm{KH}_{2} \mathrm{PO}_{4}, 3.6 ; \mathrm{Na}_{2} \mathrm{SO}_{4}$, 10 or $0 ; \mathrm{NH}_{4} \mathrm{Cl}, 6 ; \mathrm{MgSO}_{4} \cdot 7 \mathrm{H}_{2} \mathrm{O}, 0.3 ; \mathrm{CaCl}_{2} \cdot 2 \mathrm{H}_{2} \mathrm{O}, 0.4$; $\mathrm{FeSO}_{4} \cdot 7 \mathrm{H} 2 \mathrm{O}, 0.02$; a stock trace element solution, $1 \mathrm{ml} / \mathrm{l}$; a stock selenite-tungstate solution, $1 \mathrm{ml} / 1$; and a stock vitamin solution, $1 \mathrm{ml} / \mathrm{l}$. The stock trace element solution contained (mg/l): $\mathrm{H}_{3} \mathrm{BO}_{3}, 30 ; \mathrm{MnCl}_{2} \cdot 4 \mathrm{H}_{2} \mathrm{O}, 100 ; \mathrm{CoCl}_{2} \cdot 6 \mathrm{H}_{2} \mathrm{O}, 190$; $\mathrm{NiCl}_{2} \cdot 6 \mathrm{H}_{2} \mathrm{O}, 24 ; \mathrm{CuCl}_{2} \cdot 2 \mathrm{H}_{2} \mathrm{O}, 2 ; \mathrm{ZnCl}_{2}, 140$; $\mathrm{Na}_{2} \mathrm{MoO}_{4} \cdot 2 \mathrm{H}_{2} \mathrm{O}, 36$. The stock selenite-tungstate solution contained (mg/l): $\mathrm{Na}_{2} \mathrm{SeO}_{3} \cdot 5 \mathrm{H}_{2} \mathrm{O}, 6$ and $\mathrm{Na}_{2} \mathrm{WO}_{4} \cdot 2 \mathrm{H}_{2} \mathrm{O}, 8$. 
Fig. 1 Schematic representation of the experiment. Reactor R-0 was the start-up reactor. The culture in R-0 was used as an inoculum for the reactors $\mathrm{R} 1$ and R2a. The cultures were run at a dilution rate of $0.02 \mathrm{~h}^{-1}$ for five to six volume changes with each volume change of $50 \mathrm{~h}$

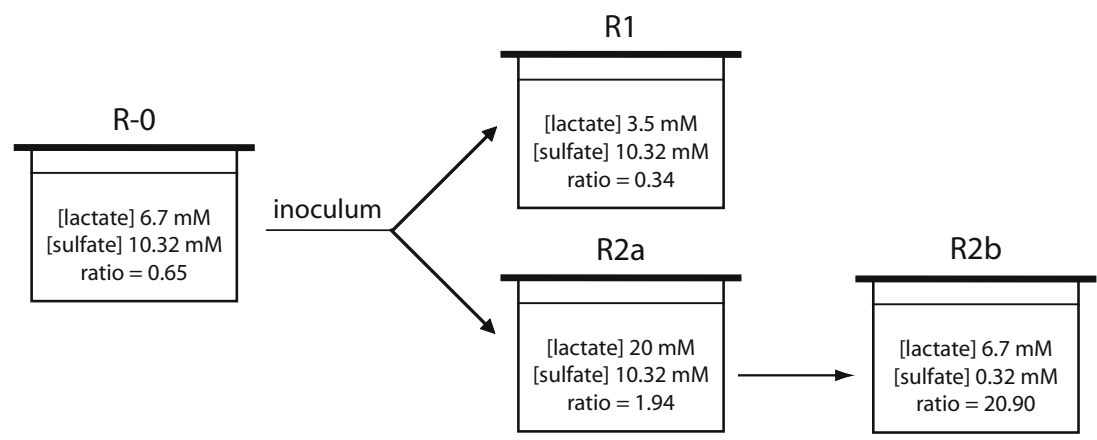

The stock vitamin solution was composed of (mg/l): biotin, 10; vitamin $\mathrm{B}_{12}, p$-aminobenzoic acid, and calcium $\mathrm{D}(+)$ pantothenate, 50; thiamine, pyridoxine- $\mathrm{HCl}$, and nicotinic acid, 100. The medium was autoclaved, and the dissolved oxygen removed from the hot media by sparging it with oxygen-free nitrogen. The medium was maintained in an oxygen-free atmosphere by continuously flushing it with nitrogen. The $\mathrm{pH}$ in the reactors was maintained at 7.5 by automatic titration with $1 \mathrm{M} \mathrm{NaOH}$ and $1 \mathrm{M} \mathrm{HCl}$. An automatic level controller maintained the working volume of 21 inside the reactor vessels. The cultures were continuously sparged with oxygen-free nitrogen to flush the gaseous $\mathrm{H}_{2} \mathrm{~S}$. Sulfide precipitated as $\mathrm{ZnS}$ after letting the gaseous $\mathrm{H}_{2} \mathrm{~S}$ through a zinc acetate trap connected to the gas exhaust of the reactor. Cultures were run at $D=0.02 \mathrm{~h}^{-1}$ for at least five to six volume changes (one volume change is $50 \mathrm{~h}$ ) and until chemical analysis of effluent showed constancy over at least two consecutive days.

\section{Chemical analysis}

Acetate and other volatile fatty acids were analyzed either by gas chromatography (GC) or by high-performance liquid chromatography (HPLC). Sulfate was analyzed by ion chromatography as described previously (Scholten and Stams 1995). Sulfide was measured quantitatively by a colorimetric assay (Cline 1969). As sulfide was stripped from the culture liquid with nitrogen to reduce sulfide toxicity, the sulfide produced was calculated from the sulfate consumed. Hence, the given sulfide values indicate minimum values.

Nucleic acid extraction, reverse transcription of RNA, and PCR amplification

Nucleic acid extraction was carried out as described previously (Dar et al. 2007b). One microliter (80-100 ng) of RNA template was used to carry out the reverse transcription (RT) of the isolated RNA into cDNA. Reverse transcription was performed using the iScript cDNA
Synthesis Kit (BioRad, California, USA) according to the manufacturer's protocol. Amplification of the $16 \mathrm{~S}$ rRNA gene fragment was performed using the primer pair $341 \mathrm{~F}$ GC and $907 \mathrm{R}$ and the protocol as described previously (Muyzer et al. 1995). Nested amplification with groupspecific primers for SRB was also performed as described previously (Dar et al. 2005). We used $1 \mu$ l of genomic DNA and $2 \mu \mathrm{l}$ of cDNA as template for the amplification reactions. The quality of the PCR products was examined on $1 \%(w / v)$ agarose gel, and the yield was quantified by absorption spectrophotometry using the Nanodrop ND1000 TM (NanoDrop Technologies, Delaware, USA).

DGGE of 16S rRNA gene fragments and phylogenetic analysis

DGGE was performed as described by Schäfer and Muyzer (2001) using the D-Code system (BioRad Laboratories, California, USA). After electrophoresis, the gels were incubated for $30 \mathrm{~min}$ in a solution containing ethidium bromide $(0.5 \mu \mathrm{g} / \mathrm{ml})$, rinsed for $20 \mathrm{~min}$ in Milli-Q water, and photographed using a BioRad GelDoc station (BioRad, California, USA). Individual bands were excised, resuspended in $20 \mu$ l of Milli-Q water, and stored overnight at $4^{\circ} \mathrm{C}$. A volume of 3 to $5 \mu$ l of the supernatant was used for reamplification with the original primer sets. The reamplified PCR products were run again on a denaturing gradient gel to check their purity. Before sequencing, the PCR products were purified using the Qiaquick PCR purification kit (QIAGEN, Hilden, Germany).

The obtained 16S rRNA gene sequences were first compared to the sequences stored in publicly accessible database using the NCBI BLAST search tool (http:/www. ncbi.nlm.nih.gov/BLAST; McGinnis and Madden 2004). Subsequently, the sequences were imported into the ARB software program (Ludwig et al. 2004) and aligned using the automatic aligner function. The alignment was further corrected manually, and an optimized tree was calculated using the neighbor-joining algorithm with Felsenstein correction. 
Design of oligonucleotide probes

Specific oligonucleotide probes for the 16S rRNA of the dominant anaerobic communities in the reactors were designed using the probe design tool of the ARB software package (Ludwig et al. 2004) as described previously (Dar et al. 2007a). The oligonucleotides used for in situ hybridisation are given in Table 1.

Fluorescence in situ hybridization

Fixed cell samples from the reactors were immobilized on Teflon-coated multiwell microscopic slides as described previously (Dar et al. 2007b). Hybridization was carried out according to the protocol as described previously (Manz et al. 1992) using a formamide concentration of $35 \%(v / v)$. Quantification of the hybridized cells was performed as described previously (Neef et al. 1996). The hybridized cells were analyzed by two independent observers for determining the fraction of positive signal from each probe relative to the signal visualized with general probes for bacteria (EUB338 I, II, and III), sulfate-reducing bacteria (SRB385 and SRB385Db), or with the general DNA stain DAPI $\left(4^{\prime}, 6^{\prime}-\right.$ diamidino-2-phenylindole). In addition, a general probe specific for members of the domain Archaea (ARC915) was used. The hybridization experiments were done in duplicate, using different fluorochromes for each probe. Different microscopic fields on each slide were analyzed to confirm the results.

Hybridization stringencies of the newly designed probes were determined by performing hybridizations with increasing formamide concentrations as described previously (Manz et al. 1992) using target organism(s) and nontarget organism displaying three mismatches within the target region.
Sequence accession numbers

The sequences determined in this study were submitted to GenBank under accession numbers EU276620-EU276626.

\section{Results}

Microbial community dynamics at different lactate/sulfate ratio

Figure 2 summarizes the effluent composition in the bioreactors, after a minimum selection period of five to six volume changes, as a function of the different lactate to sulfate ratios imposed. The start-up reactor R-0 had a lactate/sulfate ratio $\left(r=0.65 \mathrm{~mol} \mathrm{~mol}^{-1}\right)$ theoretically sufficient to allow full lactate oxidation to $\mathrm{CO}_{2}$ with sulfate (also see Table 2). The results for R1 with excess sulfate $(r=0.34 \mathrm{mo} / \mathrm{mol})$ indicate that after five to six volume changes only sulfate, sulfide, and acetate, and no other organic acids were detected in the effluent of the bioreactor (Fig. 2). Nearly all lactate (3.5 mM) had been converted to acetate $(3.2 \mathrm{mM})$ with the equivalent conversion of sulfate to sulfide. These measurements indicate partial oxidation of lactate to acetate, coupled to sulfate reduction was an important reaction in R1 (reaction 2, Table 2). At a high lactate to sulfate ratio $\left(r=1.94 \mathrm{~mol} \mathrm{~mol}^{-1}\right)$ in the reactor R2a, propionate was detected in the effluent besides acetate (Fig. 2), demonstrating that lactate was partially fermented to a propionate and acetate mixture (reaction 3, Table 2). In this sulfate-limited reactor, nearly all sulfate had been converted to sulfide. At a very low sulfate concentration $(r=20.9)$, lactate fermentation to acetate and propionate was observed as a dominant reaction (reactor R2b). The shift in the microbial population structure due to different lactate to

Table 1 Oligonucleotides used in this study

\begin{tabular}{llll}
\hline Probe name & Target organism & Probe sequence (5'-3') & Reference \\
\hline EUB338I & Most bacteria & GCT GCC TCC CGT AGG AGT & Amann et al. 1990 \\
EUB338II & Phylum Planctomycetes & GCA GCC ACC CGT AGG TGT & Daims et al. 1999 \\
EUB338III & Phylum Verrucomicrobia & GCT GCC ACC CGT AGG TGT & Daims et al. 1999 \\
ARCH915 & Archaea & GTG CTC CCC CGC CAA TTC & Stahl and Amann 1991 \\
SPS770 & Genus Sporomusa & ATC CCG TTC ACT CCC CTG & This study \\
SRB385 & Most Deltaproteobacteria & CGC GTC GCT GCG TCA GG & Amann et al. 1990 \\
SRB385Db & Some Deltaproteobacteria & CGG CGT TGC TGC GTC AGG & Rabus et al. 1996 \\
DSR660 & Genus Desulfobulbus & GAA TTC CAC TTT CCC CTC TG & Devereux et al. 1992 \\
DSM1265 & Genus Desulfomicrobium & AGA TTC GCT CGA CCT CGC & This study \\
DSV139 & Desulfovibrio sp. strain L7 & CGC TGT TAT CCC GAT CAC & Dar et al. 2007a \\
DSCOC814 & Desulfococcus group & ACC TAG TGA TCA ACG TTT & Devereux et al. 1992 \\
\hline
\end{tabular}




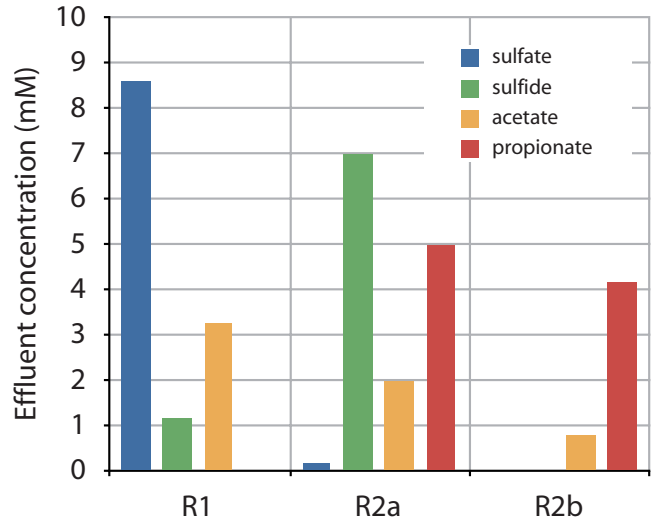

Fig. 2 Effluent concentrations of sulfide, sulfate, acetate, and propionate in reactors $\mathrm{R} 1, \mathrm{R} 2 \mathrm{a}$, and $\mathrm{R} 2 \mathrm{~b}$. The sulfide data are minimum numbers due to $\mathrm{N}_{2}$ stripping

sulfate ratios after five to six volume changes was recorded by DGGE profiling of $16 \mathrm{~S}$ rRNA gene fragments, which were amplified either from genomic DNA or from reversetranscribed RNA, i.e., cDNA.

The comparative analysis of the profiles based on the DNA and RNA of the same sample reflect not only the presence but also the actively growing populations. Figure 3 illustrates the results of the bacterial 16S rRNA-DGGE reflecting the shift in the predominant populations with the changing lactate to sulfate ratios. For the three lactate to sulfate ratios used (i.e., $r=0.34,1.94$, and 20.9), the DGGE profiles based on 16S rRNA were not identical to the $16 \mathrm{~S}$ rDNA-based profiles of the same sample. The phylogenetic affiliation of 16S rRNA gene sequences is presented in Fig. 4. A neighbor-joining tree was generated using the sequences of the DNA fragments excised from the denaturing gel. Band $\mathrm{B} 3$, representing the most persistent species of all the microbial communities in the DNA based profiles, showed high sequence similarity to the Sporomusa-Pectinatus-Selenomonas group with the closest relative being Dendrosporobacter quercicolus. The DGGE profile of the samples taken from R2a to R2b showed an increase in the intensity of fragment B3. Fragment B5 was abundant in reactors $\mathrm{R} 1$ and $\mathrm{R} 2 \mathrm{a}$ but with varying degrees of intensity. The fragment was not only persistently present but also belonged to an actively growing population as suggested by its simultaneous presence in the RNA-based profiles. However, the fragment was not present in the DGGE profile when the sulfate feed to the reactor $\mathrm{R} 2 \mathrm{~b}$ was brought down $(r=20.9)$. Comparative sequence analysis showed that band B5 clustered with the genus Desulfovibrio with Desulfovibrio mexicoense as the closest relative among the cultured representatives. Fragment B6, which was also significantly present, especially in the RNA-based profiles of $\mathrm{R} 1$ and $\mathrm{R} 2 \mathrm{a}$, was related to the members of genus Desulfobulbus with the closest relative being Desulfobulbus rhabdoformis. Band B4 was observed only in R1 maintained at a limiting lactate concentration $\left(r=0.34 \mathrm{~mol} \mathrm{~mol}^{-1}\right)$. The fragment was found closely related to Desulfomicrobium apsheronum. Two other fragments excised, band B1 and band B2, although present, did not form a significant proportion of the active microbial communities in $\mathrm{R} 1$ and $\mathrm{R} 2$ as indicated by the RNA-based profiles. The two fragments were affiliated to an uncultured group of Cytophaga and Spirochetes, respectively. Nested amplification with group-specific primers (results not shown) resulted in the identification of an acetate-utilizing SRB represented by band B7. The sequence of the fragment was found closely related to Desulfococcus biacutus.

The archaeal 16S rRNA gene-targeted DGGE indicated that the diversity was limited to a single species (results not shown) and it was found at all lactate to sulfate ratios except the lowest ratio $(r=0.34)$ with $3.5 \mathrm{mM}$ lactate. Sequence analysis of the excised fragment indicated its close relatedness to a group of uncultured Archaea distantly related to Methanosaeta sp.

\section{Microbial community dynamics using FISH}

The FISH results were obtained using oligonucleotide probes that targeted dominant microbial communities present under different substrate concentrations. The results are presented as relative abundances of populations targeted by specific probes and are expressed as the percentage of

Table 2 Stoichiometry of anaerobic degradation reactions relevant to this study

\begin{tabular}{lll}
\hline No. & Reaction & $\Delta G^{01} \mathrm{~kJ}^{2}$ reaction \\
\hline 1 & $\mathrm{C}_{3} \mathrm{H}_{5} \mathrm{O}_{3}^{-1}+1.5 \cdot \mathrm{SO}_{4}^{-2} \rightarrow 3 \cdot \mathrm{HCO}_{3}^{-1}+1.5 \cdot \mathrm{HS}^{-1}+0.5 \cdot \mathrm{H}^{+1}$ & -128.5 \\
2 & $\mathrm{C}_{3} \mathrm{H}_{5} \mathrm{O}_{3}^{-1}+0.5 \cdot \mathrm{SO}_{4}^{-2} \rightarrow \mathrm{C}_{2} \mathrm{H}_{3} \mathrm{O}_{2}^{-1}+\mathrm{HCO}_{3}^{-1}+0.5 \cdot \mathrm{HS}^{-1}+0.5 \cdot \mathrm{H}^{+1}$ & -80.8 \\
3 & $\mathrm{C}_{3} \mathrm{H}_{5} \mathrm{O}_{3}^{-1} \rightarrow 0.33 \cdot \mathrm{C}_{2} \mathrm{H}_{3} \mathrm{O}_{2}^{-1}+0.67 \cdot \mathrm{C}_{3} \mathrm{H}_{5} \mathrm{O}_{2}^{-1}+0.33 \cdot \mathrm{HCO}_{3}^{-1}+0.33 \cdot \mathrm{H}^{+1}$ & -55.7 \\
4 & $\mathrm{C}_{3} \mathrm{H}_{5} \mathrm{O}_{2}^{-1}+0.75 \cdot \mathrm{SO}_{4}^{-2} \rightarrow \mathrm{C}_{2} \mathrm{H}_{3} \mathrm{O}_{2}^{-1}+\mathrm{HCO}_{3}^{-1}+0.75 \cdot \mathrm{HS}^{-1}+0.25 \cdot \mathrm{H}^{+1}$ & -37.7 \\
5 & $\mathrm{C}_{3} \mathrm{H}_{5} \mathrm{O}_{2}^{-1}+1.75 \cdot \mathrm{SO}_{4}^{-2} \rightarrow 3 \cdot \mathrm{HCO}_{3}^{-1}+1.75 \cdot \mathrm{HS}^{-1}+0.25 \cdot \mathrm{H}^{+1}$ & -85.4 \\
6 & $\mathrm{C}_{2} \mathrm{H}_{3} \mathrm{O}_{2}^{-1}+\mathrm{H}_{2} \mathrm{O} \rightarrow \mathrm{CH}_{4}+\mathrm{HCO}_{3}^{-1}$ & -31.1 \\
\hline
\end{tabular}




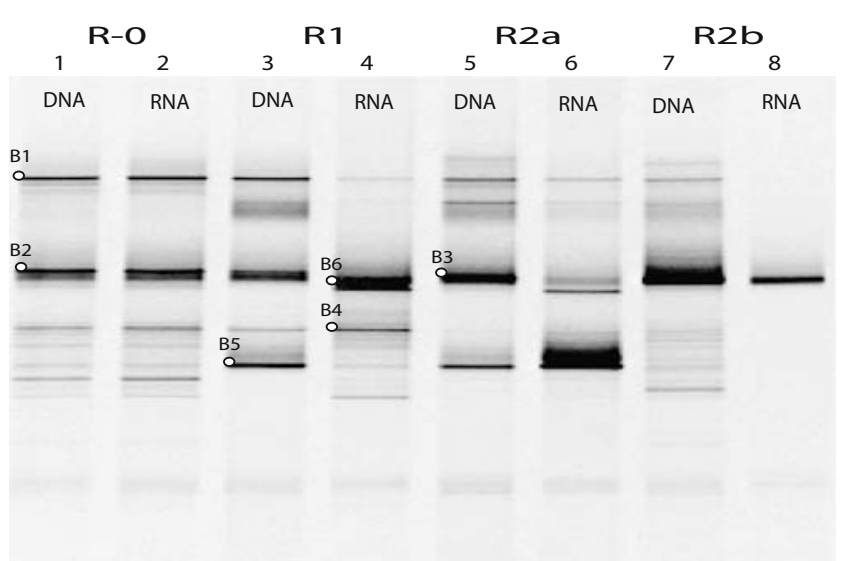

Fig. 3 DGGE analysis of 16S rRNA gene fragments using DNA and RNA samples from reactors R-0, R1, R2a, and R2b. Lanes 1 (DNA) and 2 (RNA) sample from reactor R-0 (influent lactate $6.7 \mathrm{mM}$ ); lanes 3 (DNA) and 4 (RNA) sample from reactor R1 (influent lactate $3.5 \mathrm{mM}$ ); lanes 5 (DNA) and 6 (RNA) from reactor R2a (influent lactate $20 \mathrm{mM}$ ); lanes 7 (DNA) and 8 (RNA) from reactor R2b (in the near absence of sulfate). Bands indicated with a dot were excised and sequenced

the total positive signal obtained by general probes for bacteria (EUB338 I, II, and III) or with the general DNA stain DAPI (4',6'-diamidino-2-phenylindole). In addition, the general probe specific to Archaea (ARC915) gave a measure of Archaea. The percentage abundance of the specific probes relative to the general probes is summarized in Fig. 5a and b. In general, probe EUB338 stained more than $90 \%$ of all the cells in the samples. Probe SPS770 specifically targeted the species that was closely related to D. quercicolus. At the influent lactate concentration of $3.5 \mathrm{mM}$ (reactor R1), the relative abundance of this organism was $<2 \%$ of the total bacterial population (Fig. 5a and 6b). When compared to the start-up reactor $\mathrm{R}-0$, the relative abundance of the cells targeted by probe SPS770 was $8-10 \%$ of the total bacterial cells (Fig. 5a and $6 a)$. The relative percentage of cells that hybridized with this probe was significantly higher $(40-45 \%$ of the total bacterial cells), in samples taken from reactor R2a (lactate excess, $20 \mathrm{mM}$; Fig. 5a and 6c) and increasing even higher to more than $70 \%$ (Fig. $5 \mathrm{a}$ and $6 \mathrm{~d}$ ), when the sulfate feed to reactor R2b was minimized. Probes DSR660, DSV139, and DSM1265 were used to target different sulfate-reducing communities (Table 1) that were identified in the reactor samples using DGGE. Desulfomicrobium-like SRB targeted by probe DSM1265 were present in high proportions at excess sulfate (reactor R1, $r=0.34 \mathrm{~mol} \mathrm{~mol}^{-1}$ ). The percentage abundance relative to the total bacteria was more than $65 \%$ compared to $15-20 \%$ in the inoculum (R-0; Fig. $5 b)$. The numbers were about $5-8 \%$ at limiting sulfate concentrations in reactor $\mathrm{R} 2 \mathrm{a}(r=1.94)$ and decreased
Fig. 4 Phylogenetic tree based on 16S rRNA gene sequences obtained from the DGGE bands (see Fig. 3). Sequences determined in this study are in boldface. Black dots on the nodes indicate bootstrap values of $90 \%$ and higher (1,000 replicates). The scale bar indicates $10 \%$ sequence difference

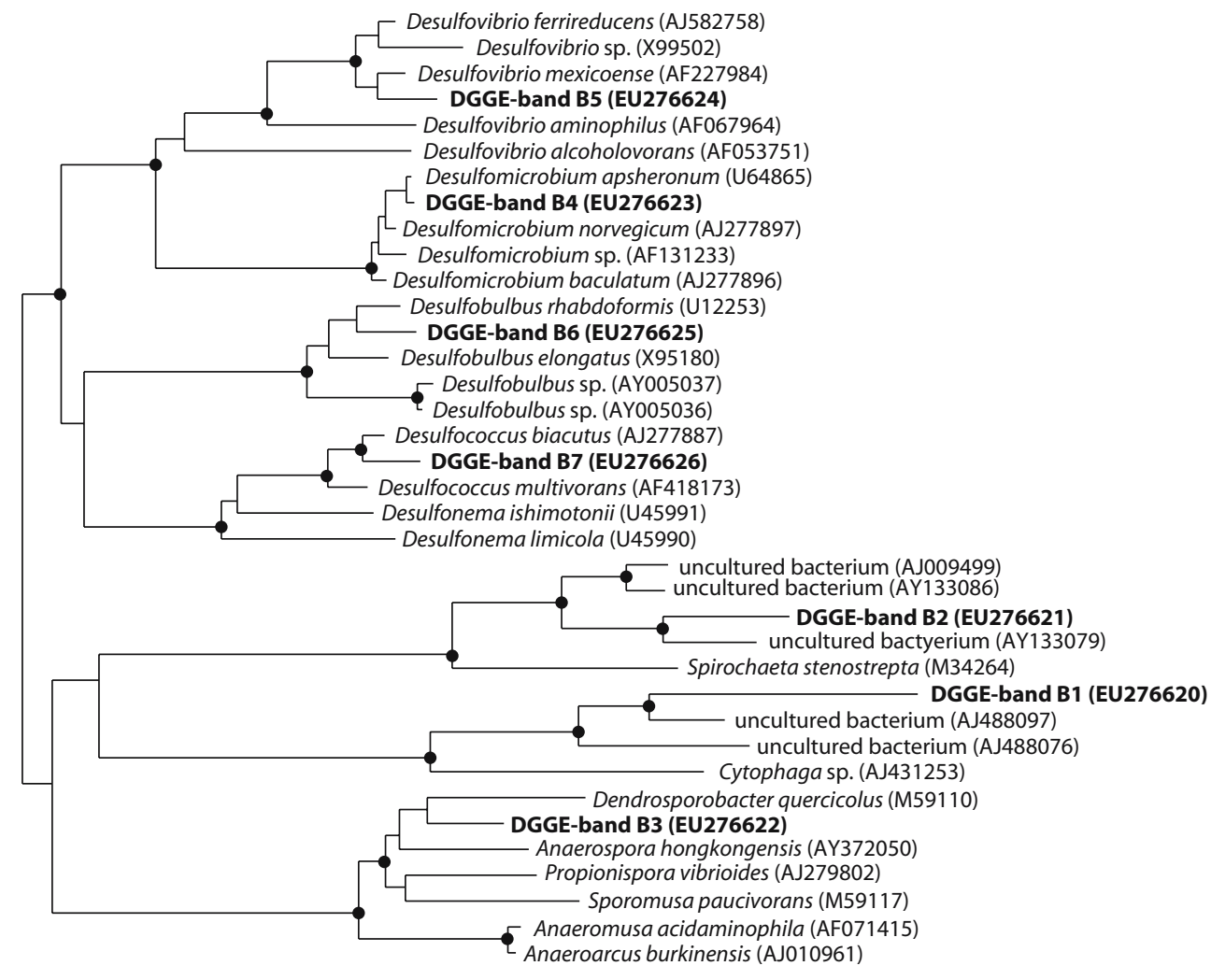

0.10 

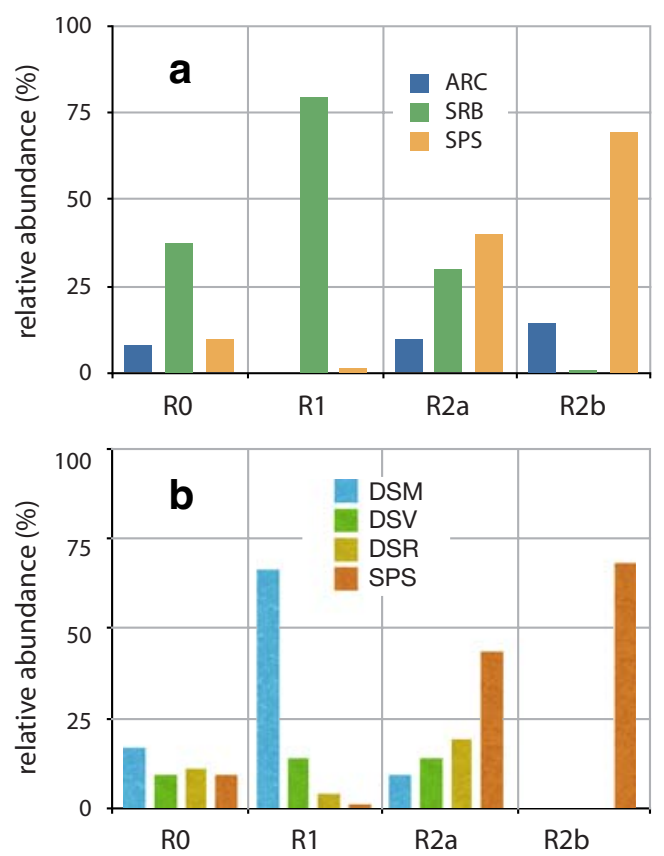

Fig. 5 a Relative abundance of Archaea, sulfate-reducing bacteria, and acetogenic bacteria. b Relative abundance of Desulfomicrobium-, Desulfovibrio-, Desulfobulbus-, and Dendrosporobacter-like bacteria. The percentage abundance is relative to the signal obtained with probe EUBmix

further to undetectable levels in the virtual absence of sulfate in reactor R2b $(r=20.9)$. Desulfovibrio-like SRB targeted by probe DSV139 were the most resilient of all the SRB. Their numbers did not change significantly, fluctuating between $10 \%$ and $7 \%$ of the total bacteria in the two reactors R1 and R2-a, respectively (Fig. 5b). They were reduced to undetectable levels when the sulfate supply to reactor R2-b was virtually stopped.

The relative abundance of Desulfobulbus-like SRB targeted by probe DSR660 showed the most significant increase among all SRB detected, responding to an increase in lactate concentration combined with sulfate limitation. The percentage abundance increased from about $10-12 \%$ in the inoculum (reactor R-0; Fig. 5 b) to about $20 \%$ of the total bacteria in reactor R2a maintained at limiting sulfate concentration ( $r=1.94)$. In reactor R1 (i.e., at sulfate excess conditions), the Desulfobulbus-like SRB were $<5 \%$ of the total bacteria (Fig. 5b).

The change to a low sulfate concentration in the reactor resulted in a considerable increase in the methanogenic population. FISH with probe ARCH915 indicated an increase of the methanogenic population from $5 \%$ in the inoculum (R-0) to more than $10-15 \%$ under limiting sulfate (R2-a) and nonsulfidogenic (R2-b) conditions (Fig. 5a). The relative abundance of the methanogenic population decreased to undetectable levels after the shift from R-0 to the lactate-limited reactor R1.

\section{Discussion}

This study evaluates the shift in microbial structure in labscale CSTR reactors as affected by changing lactate to sulfate ratios using a combined approach of molecular methods (PCR-DGGE and FISH) and chemical analysis. The combination of different methods allowed the establishment of a link between the population structure and function of the anaerobic communities in the reactors under sulfidogenic and nonsulfidogenic conditions.

PCR-DGGE profiles produced using DNA templates may not reflect the dynamic changes in community structure. Metabolically active cells have a much higher ratio of rRNA to DNA than dormant cells (Weller and Ward 1989). Therefore, the use of rRNA templates may emphasize the actively growing populations in the community as opposed to those that are relatively inactive but persistent in the community. Because PCR-based approaches for the analysis of microbial diversity in mixed populations can be influenced by several constraints (von Wintzingerode et al. 1997), our results based on PCR-DGGE do not necessarily reflect the abundance of target sequences in the reactor samples. We, therefore, tried to confirm the relevance of the sequence data by whole-cell hybridization using fluorescently labeled oligonucleotide probes.

Depending on different lactate to sulfate ratios, theoretically, various scenarios involving SRB in the degradation of lactate are possible as shown in Table 2.

1. Complete oxidation of lactate to $\mathrm{CO}_{2}$ and sulfide by SRB (reaction 1, Table 2).

2. Incomplete oxidation of lactate to acetate by SRB (reaction 2, Table 2).

3. Fermentative degradation of lactate to propionate and acetate and the utilization of fermentation products by SRB and acetoclastic methanogens (reactions 3, 4, 5, and 6, Table 2).

4. In the absence of sulfate the fermentative degradation of lactate coupled to acetoclastic methanogens (reactions 3 and 6 , Table 2).

The net metabolic pathway of the degradation of lactate by a mixed culture inoculum used in this study suggests its dependence upon the relative quantities of lactate and sulfate. Theoretically, the complete oxidation of lactate to inorganic carbon requires a minimum lactate to sulfate ratio of $0.67 \mathrm{~mol} \mathrm{~mol}^{-1}$ (reaction 1, Table 2) and if the ratio is below 0.67 , additional electron donor is required for complete sulfate reduction. At lower molar ratio of lactate to sulfate (0.34 mol mol ${ }^{-1}$, reactor R1), only sulfate, sulfide, and acetate were detected in the effluent. These results directly show the quantitative oxidation of lactate to acetate coupled to sulfate reduction as a dominant reaction (reaction 2, Table 2). This is consistent with high percentage abundance 

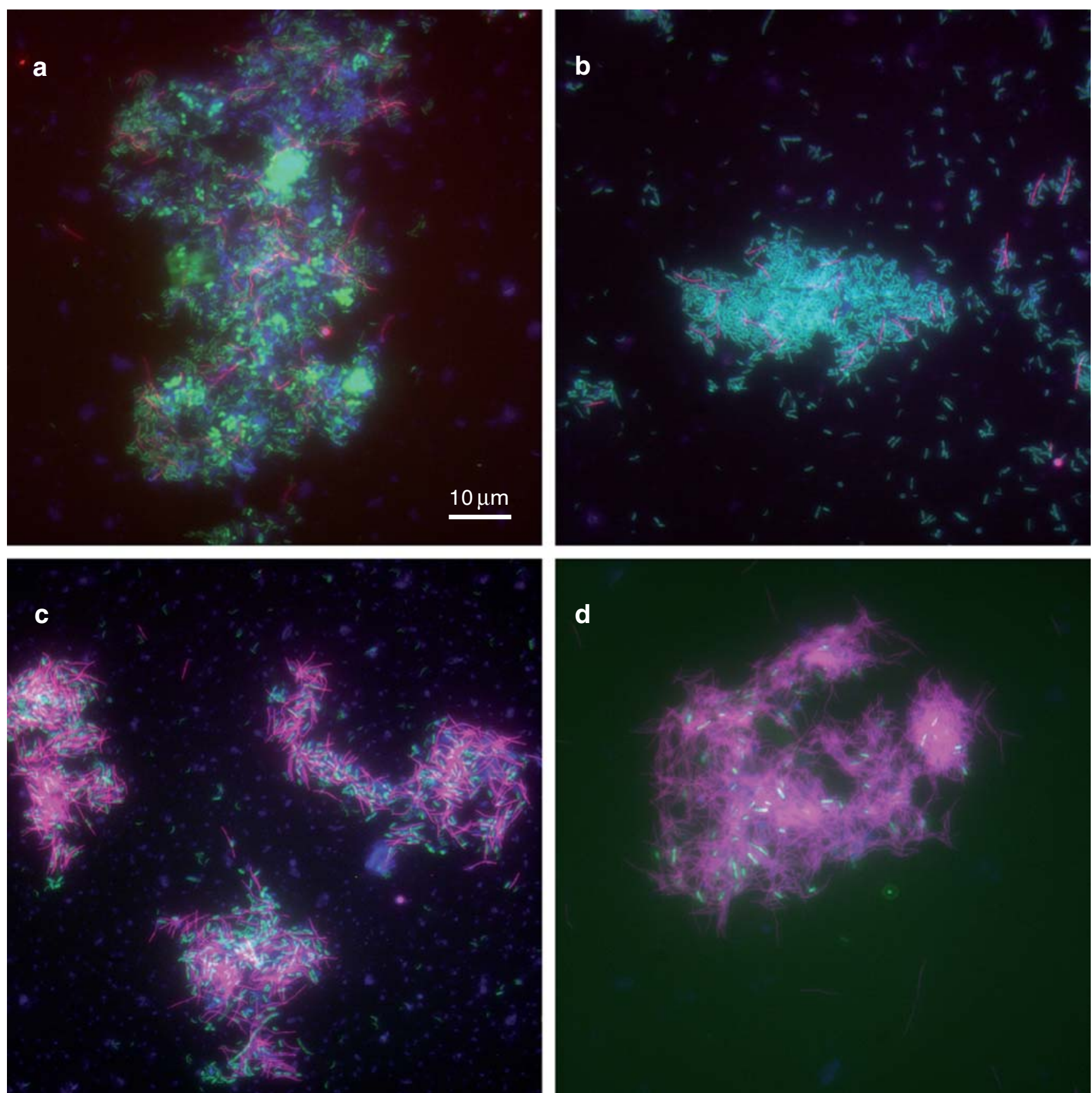

Fig. 6 Whole-cell hybridization of samples from reactors R-0, R1, $\mathrm{R} 2 \mathrm{a}$, and R2b probe EUBmix labeled with Cy5 (blue), probe SRB385 and 385Db labeled with Fluos (green), and probe SPS770 labeled with

of Desulfomicrobium- and Desulfovibrio-like SRB (known, incompletely oxidizing, SRB capable of performing reaction 2, Table 2; Figs. 5a and 6b; Widdel 1988). Complete lactate oxidation to carbon dioxide with sulfate as electron acceptor would be energetically favorable (reaction 1, Table 2). However, the kinetics of this complete oxidation may not enable efficient competition with the incomplete lactate oxidizers. This is evident from the observation that in batch culture in the presence of excess sulfate, incompletely oxidizing SRB outcompete completely oxi-

d

Cy3 (red). a Reactor R-0 (influent lactate $6.7 \mathrm{mM}$ ); b reactor R1 (influent lactate $3.5 \mathrm{mM}$ ); $\mathbf{c}$ reactor $\mathrm{R} 2 \mathrm{a}$ (influent lactate $20 \mathrm{mM}$ ); d reactor $\mathrm{R} 2 \mathrm{~b}$ (in the near absence of sulfate)

dizing species due to their superior maximum specific growth rate on fermentation intermediates like lactate, ethanol, propionate, etc. (McCartney and Oleszkiewicz 1993; Widdel 1988). The actual competition between partial and complete lactate oxidizing SRBs will be determined by the affinity for lactate $\left(\mu_{\max } / K_{\mathrm{s}}\right)$.

Given the fact that the nested amplification suggested that the numbers of the complete oxidizers were very low in the inoculum, a long period of time would have been required before such SRB would have grown to a 
significant number. Therefore, we cannot rule out that eventually the complete oxidizers might have become dominant under lactate-limiting conditions in R1.

In the near absence of sulfate, lactate fermentation to acetate and propionate (reaction 3, Table 2) was observed as a dominant reaction in the reactor $\mathrm{R} 2 \mathrm{~b}$. This was reflected by a significant increase in the relative abundance of Dendrosporobacter-like species and a near washout of SRB species (Fig. 5a and 6d). D. quercicolus is an obligate anaerobe that clusters with the Sporomusa-PectinatusSelenomonas group (Strompl et al. 2000). The members of this group are known to perform acetogenic and propionic acid fermentation (reaction 3, Table 2; Biebl et al. 2000). Major fermentation products of D. quercicolus and other closely-related members of the group are acetate and propionate. Theoretically (reaction 3, Table 2), the fermentation of $6.7 \mathrm{mM}$ of lactate should yield approximately $4 \mathrm{mM}$ of propionate and $2 \mathrm{mM}$ of acetate assuming that $0.5 \mathrm{mM}$ is assimilated into the biomass. However, the acetate concentration in the effluent of the reactor $\mathrm{R} 2 \mathrm{~b}$ (Fig. 2) indicated a net loss of $15 \%$ of the electron donor. The plausible explanation for this loss can be acetoclastic methanogenesis (reaction 6, Table 2) that can be assumed from an increase in the methanogenic population to $15 \%$ under nonsulfidogenic conditions (Fig. 5a).

The lactate to sulfate molar ratio in reactor R2a $(1.94 \mathrm{~mol}$ $\mathrm{mol}^{-1}$ ) was increased by a factor of three compared to the inoculum, reactor R-0 $\left(0.67 \mathrm{~mol} \mathrm{~mol}^{-1}\right)$ and a factor of about six compared to reactor R1 $\left(0.34 \mathrm{~mol} \mathrm{~mol}^{-1}\right)$. The conditions in reactor R2a were changed to sulfate limitation with a substantial increase in influent lactate concentrations. Indeed, the sulfate concentration had dropped to $<0.2 \mathrm{mM}$, showing that the SRBs could no longer compete for the remainder of the substrates. The products in the effluent included propionate and acetate besides sulfide, suggesting that lactate was partially fermented to a propionate and acetate mixture (reaction 3 , Table 2). This indicates a change in the net metabolic pathway for the degradation of lactate compared to the reactor R1. This change may be attributed to the lactate fermenting bacteria catalyzing reaction 3 (Table 2). The same is suggested by a significant increase in the population of $D$. quercicolus-like species, 5 times increase relative to reactor R-0 and even 20-25 times relative to reactor R1 (Fig. 5a and 6c). This is in agreement with the previous studies performed (McCartney and Oleszkiewicz 1993; Mendez et al. 1989; Pichon et al. 1988; Ueki et al. 1986). In all these studies, an increase in the buildup of propionate was observed with increasing organic substrate to sulfate ratio. McCartney and Oleszkiewicz (1993) attributed this change to the net metabolism of lactate, the combined influence of the increased lactate to sulfate ratio, and the time for which the culture was exposed to excess sulfate. This is clearly also the case in our experiments: if a steady state has been reached, the DNA and RNA bands in the DGGE are expected to be similar, if not identical. As demonstrated in Fig. 3, this was not the case. Again, if growth rates would have been only marginally different, a true steady state might have taken several weeks to become established, and hence, we cannot rule out that we have looked at a snapshot during a shift in the population. In this study, the exposure of the original inoculum from the anaerobic wastewater plant to excess sulfate was approximately 13 days during start-up reactor, $\mathrm{R}-0$, before an increase in the lactate to sulfate ratio was imposed in reactor R2a $\left(1.94 \mathrm{~mol} \mathrm{~mol}^{-1}\right)$. This exposure time was enough to enrich SRB in sufficiently high numbers for the development of substantial sulfidogenesis leading to sulfate depletion. As pointed out above, the consequence was that the culture runs into sulfate limitation and, under this condition, acetogens and methanogens experience no competition for the remaining substrate. It is interesting to note that the buildup of propionate in reactor R2a was concurrent to the increase in D. rhabdoformis-like SRB (Fig. 5b), which are known to degrade propionate (reaction 4 , Table 2). This increase in the relative abundance of $D$. rhabdoformis-like $\mathrm{SRB}$, suggesting a synergistic association between heteroacetogenic bacteria and SRB, is a feasible scenario in the presence of limiting sulfate.

An overall electron balance over the system was established, assuming a biomass yield of $0.07^{\circ} \mathrm{C}-\mathrm{mol} \mathrm{C}-\mathrm{mol}^{-1}$. In the experiment, at a lactate to sulfate ratio of $0.34 \mathrm{~mol}$ $\mathrm{mol}^{-1}$ (reactor R1), the electron balance was nearly $95 \%$. However, in the other experiments with R2, a net loss of reduction equivalents between $10 \%$ and $50 \%$ is observed. This may be attributed to methane or $\mathrm{H}_{2}$ formations, which were stripped out with the sulfide. Assuming the dominance of partial lactate oxidation coupled to sulfate reduction in reactor $\mathrm{R} 1\left(0.35 \mathrm{~mol} \mathrm{~mol}{ }^{-1}\right)$ and a partial lactate fermentation to propionate and acetate in reactor R2-a $\left(1.94 \mathrm{~mol} \mathrm{~mol}^{-1}\right)$, both $\mathrm{H} 2$ and acetate are the most plausible precursor for methane formation. However, the observation that relatively high concentrations of acetate were found in the reactor effluent $(1-4 \mathrm{mM})$ and the detection of methanogenic Archaea which clustered with Methanoseata sp. suggests that, given the dilution rate of $0.02 \mathrm{~h}^{-1}$, only a low affinity acetoclastic methanogen catalyzing reaction (reaction 6 , Table 2) could be maintained in the system. These results were consistent with the increase in the percentage abundance of methanogenic Archaea to more than $10-15 \%$ of the total DAPI-stained cells. Because the conditions in the reactors did not favor the growth of nonmethanogenic Archaea (extreme halophiles, thermoacidophiles, the Archaeoglobales, and thermophiles placed in Crenarchaeota kingdom; Woese 1987), cells targeted by probe ARCH915 can be assumed to be the total methanogenic representation in this environment. 
In conclusion, this study points to different metabolic routes being followed by a mixed anaerobic community, even in the mineralization of simple substrates like lactate. We could establish a link in microbial population dynamics to major perturbations caused by changing influent lactate to sulfate ratios. This study demonstrated that at low lactate to sulfate molar ratios in the influent, SRB had a competitive advantage over acetogens and methanogens and that, in the near absence of sulfate, heteroacetogens formed a syntropic association with methanogens. Higher lactate to sulfate ratio resulted in a pathway that had propionate and acetate as products, and the majority of sulfidogenesis and methanogenesis was dependent on the fermentation products. All these results were substantiated by corresponding shifts in relative abundance of the microbial communities present as analyzed by DGGE and FISH.

Acknowledgments We thank the Dutch Science Foundation (NWO) for the financial support.

Open Access This article is distributed under the terms of the Creative Commons Attribution Noncommercial License which permits any noncommercial use, distribution, and reproduction in any medium, provided the original author(s) and source are credited.

\section{References}

Amann RI, Binder BJ, Olson RJ, Chisholm SW, Devereux R, Stahl DA (1990) Combination of 16S rRNA-targeted oligonucleotide probes with flow cytometry for analyzing mixed microbial populations. Appl Environ Microbiol 56:1919-1925

Amann RI, Ludwig W, Schleifer KH (1995) Phylogenetic identification and in situ detection of individual microbial cells without cultivation. Microbiol Rev 59:143-169

Annachhatre AP, Suktrakoolvait S (2001) Biological sulfate reduction using molasses as a carbon source. Water Environ Res 73:118-126

Behrens S, Ruhland C, Inacio J, Huber H, Fonseca A, SpencerMartins I, Fuchs BM, Amann R (2003) In situ accessibility of small-subunit rRNA of members of the domains Bacteria, Archaea, and Eucarya to Cy3-labeled oligonucleotide probes. Appl Environ Microbiol 69:1748-1758

Biebl H, Schwab-Hanisch H, Sproer C, Lunsdorf H (2000) Propionispora vibrioides, nov. gen., nov. sp., a new gram-negative, spore-forming anaerobe that ferments sugar alcohols. Arch Microbiol 174:239247

Choi E, Rim JM (1991) Competition and inhibition of sulfate reducers and methane reducers in anaerobic treatment. Water Sci Technol 23:1259-1264

Cline JD (1969) Spectrophotometric determination of hydrogen sulfide in natural waters. Limnol Oceanogr 14:454-458

Daims H, Bruhl A, Amann R, Schleifer KH, Wagner M (1999) The domain-specific probe EUB338 is insufficient for the detection of all Bacteria: development and evaluation of a more comprehensive probe set. Syst Appl Microbiol 22:434-444

Dar SA, Kuenen JG, Muyzer G (2005) Nested PCR-denaturing gradient gel electrophoresis approach to determine the diversity of sulfate-reducing bacteria in complex microbial communities. Appl Environ Microbiol 71:2325-2330
Dar SA, Stams AJM, Kuenen JG, Muyzer G (2007a) Coexistence of physiologically similar sulfate reducing bacteria in a full-scale sulfidogenic bioreactor fed with a single organic electron donor. Appl Microbiol Biotechnol 75:1463-1472

Dar SA, Yao L, van Dongen U, Kuenen JG, Muyzer G (2007b) Analysis of diversity and activity of sulfate reducing bacterial communities in sulfidogenic bioreactors using 16S rRNA and dsrB genes as molecular markers. Appl Environ Microbiol 73:594-604

Devereux R, Kane MD, Winfrey J, Stahl DA (1992) Genus- and group-specific hybridization probes for determinative and environmental studies of sulfate-reducing bacteria. Syst Appl Microbiol 15:601-609

Drake HL (1994) Acetogenesis, acetogenic bacteria, and the acetyl-CoA "Wood/Ljungdahl" pathway: past and current perspectives. In: Drake HL (ed) Acetogenesis. Chapman and Hall, New York, NY

Isa Z, Grusenmeyer S, Verstraete W (1986) Sulfate reduction relative to methane production in high-rate anaerobic digestion: microbiological aspects. Appl Environ Microbiol 51:580-587

Lens PNL, Visser A, Janssen AJH, Hulshoff Pol LL, Lettinga G (1998) Biotechnological treatment of sulfate-rich wastewaters. Crit Rev Environ Sci Technol 28:41-88

Ludwig W, Strunk O, Westram R, Richter L, Meier H, Yadhukumar, Buchner A, Lai T, Steppi S, Jobb G, Forster W, Brettske I, Gerber S, Ginhart AW, Gross O, Grumann S, Hermann S, Jost R, Konig A, Liss T, Lussmann R, May M, Nonhoff B, Reichel B, Strehlow R, Stamatakis A, Stuckmann N, Vilbig A, Lenke M, Ludwig T, Bode A, Schleifer KH (2004) ARB: a software environment for sequence data. Nucleic Acids Res 32:1363-1371

Manz W, Amann R, Ludwig W, Wagner M, Schleifer KH (1992) Phylogenetic oligodeoxynucleotide probes for the major subclasses of proteobacteria: problems and solutions. Syst Appl Microbiol 15:593-600

McCartney DM, Oleszkiewicz JA (1993) Competition between methanogens and sulfate reducers: effect of COD:sulfate ratio and acclimation. Water Environ Res 65:655-664

McGinnis S, Madden TL (2004) BLAST: at the core of a powerful and diverse set of sequence analysis tools. Nucleic Acids Res 32:20-25

Mendez R, ten Brummeler E, Hulshoffpol LW (1989) Start up of UASB reactors treating sucrose containing substrates with low COD/sulfate ratio. Environ Technol Lett 10:83-90

Mizuno O, Li YY, Noike T (1994) Effects of sulfate concentration and sludge retention time on the interaction between methane production and sulfate reduction for butyrate. Water Sci Technol 30:45-54

Muyzer G, de Waal EC, Uitterlinden AG (1993) Profiling of complex microbial populations by denaturing gradient gel electrophoresis analysis of polymerase chain reaction-amplified genes coding for 16S rRNA. Appl Environ Microbiol 59:695-700

Muyzer G, Teske A, Wirsen CO, Jannasch HW (1995) Phylogenetic relationships of Thiomicrospira species and their identification in deep-sea hydrothermal vent samples by denaturing gradient gel electrophoresis of $16 \mathrm{~S}$ rDNA fragments. Arch Microbiol 164:165-172

Neef A, Zaglauer A, Meier H, Amann R, Lemmer H, Schleifer KH (1996) Population analysis in a denitrifying sand filter: conventional and in situ identification of Paracoccus spp. in methanol-fed biofilms. Appl Environ Microbiol 62:4329-4339

Pichon M, Rouger J, Junet E (1988) Anaerobic treatment of sulfur containing effluents. Water Sci Technol 20:133-141

Rabus R, Fukui M, Wilkes H, Widdle F (1996) Degradative capacities and 16S rRNA-targeted whole-cell hybridization of sulfatereducing bacteria in an anaerobic enrichment culture utilizing alkylbenzenes from crude oil. Appl Environ Microbiol 62:36053613 
Schäfer H, Muyzer G (2001) Denaturing gradient gel electrophoresis in marine microbial ecology. In: Paul JH (ed) Methods in microbiology, marine microbiology. Academic, New York, pp 425-468

Schink B (1992) Syntrophism among procaryotes. In: Balows A, Truper HG, Dworkin M, Harder W, Schleifer K-H (eds) The prokaryotes. Springer, New York, pp 276-299

Scholten JC, Stams AJ (1995) The effect of sulfate and nitrate on methane formation in a freshwater sediment. Antonie Van Leeuwenhoek 68:309-315

Seeliger S, Janssen PH, Schink B (2002) Energetics and kinetics of lactate fermentation to acetate and propionate via methylmalonylCoA or acrylyl-CoA. FEMS Microbiol Lett 211:65-70

Stahl DA, Amann R (1991) Development and application of nucleic acid probes. In: Stackebrandt E, Goodfellow M (eds) Nucleic acid techniques in bacterial systematics. Wiley, Chichester, England, pp 205-248

Stams AJ (1994) Metabolic interactions between anaerobic bacteria in methanogenic environments. Antonie Van Leeuwenhoek 66:271-294

Stams AJM, Plugge CM, de Bok FAM, van Houten BHGW, Lens P, Dijkman H (2005) Metabolic interactions in methanogenic and sulfate-reducing bioreactors. Water Sci Technol 52:13-20

Strompl C, Tindall BJ, Lunsdorf H, Wong TY, Moore ER, Hippe H (2000) Reclassification of Clostridium quercicolum as Dendro- sporobacter quercicolus gen. nov., comb. nov. Int J Syst Evol Microbiol 50(Pt 1):101-106

Thauer RK, Jungermann K, Decker K (1977) Energy conservation in chemotrophic anaerobic bacteria. Bacteriol Rev 41:100-180

Ueki A, Matsuda K, Ohtsuki C (1986) Sulfate reduction in the anaerobic digestion of animal waste. J Gen Appl Microbiol 32:111-123

von Wintzingerode F, Gobel UB, Stackebrandt E (1997) Determination of microbial diversity in environmental samples: pitfalls of PCR-based rRNA analysis. FEMS Microbiol Rev 21:213-229

Ward DM, Winfrey MR (1985) Interactions between methanogenic and sulfate-reducing bacteria in sediments. Adv Aquat Microbiol 3:141-179

Weijma J, Gubbels F, Hulshoff Pol LW, Stams AJM, Lens P, Lettinga $\mathrm{G}$ (2002) Competition for $\mathrm{H}_{2}$ between sulfate reducers, methanogens and homoacetogens in a gas-lift reactor. Water Sci Technol 45:75-80

Weller R, Ward DM (1989) Selective Recovery of 16S rRNA Sequences from natural microbial communities in the form of cDNA. Appl Environ Microbiol 55:1818-1822

Widdel F (1988) Microbiology and ecology of sulfate reducing bacteria. In: Zehnder AJB (ed) Biology of anaerobic microorganism. Wiley, New York, pp 469-585

Woese CR (1987) Bacterial evolution. Microbiol Rev 51:221-271 